\title{
PENGARUH PEMBERIAN PISANG KEPOK (Musa Paradisiaca Forma Typical) TERHADAP KADAR MALONDIALDEHYDE (MDA) TIKUS SPRAGUE DAWLEY PRA-SINDROM METABOLIK
}

\author{
Sari Puspitasari A.P, Ahmad Syauqy ${ }^{*}$ \\ Program Studi Ilmu Gizi Fakultas Kedokteran Universitas Diponegoro \\ Jl.Dr.Sutomo No.18, Semarang, Telp (024) 8453708, Email : gizifk@ undip.ac.id
}

\begin{abstract}
Background: The increasing prevalence of metabolic syndrome contributes to the increase incidence of cardiovascular disease and diabetes mellitus. The condition of hypercholesterolemia, high LDL-cholesterol, and hyperglycemia in patients with metabolic syndrome indicate an accumulation of free radicals. The increase of free radicals and the decrease of antioxidant defense mechanisms result in an increase of the oxidative stress degree that can be represented by MDA level. "Kepok" banana contains of antioxidants, vitamins, fibers, inulin and resistant starch which are potential to reduce the levels of MDA through preventing lipid oxidation. This study aims to determine the effect of "kepok" banana on liver MDA levels in pre-metabolic syndrome rats.

Methods: The study is experimental post-test only with a randomized control group design. A total of 28 Sprague Dawley pre-metabolic syndrome rats were randomly divided into 4 groups: $K$ - (only given standard feed), K+ (standard feed and induction of STZ (Streptozotocin)and NAD (nicotinamide)), and two treatment groups (standard feed, the induction of STZ, $N A D$, and "kepok" banana with a dose of $4,5 \mathrm{~g} / 200 \mathrm{gBW}$ and $9 \mathrm{~g} / 200 \mathrm{gBW}$, respectively for 21 days). TBARS (2-thiobarbituric Acid Reactive Substance) method is used to determine the MDA level. The data were analyzed by Anova and post-hoc LSD.

Results: There are differences in the levels of MDA between $K-, K+, P 1, P 2(p=0.000)$. The MDA level of P2 was lower than $K+$ and $P 1$, but higher than $K$-. The results of post-hoc LSD test on intergroup MDA levels differences showed the significance of $p=0.000$.

Conclusion: The administration of "kepok"banana at a dose of $9 \mathrm{~g} / 200 \mathrm{gBW} /$ day for 21 days can make the levels of MDA in pre-metabolic syndrome rats become lower.
\end{abstract}

Keyword : "kepok" banana, antioxidant, inulin, malondialdehyde (MDA) level

\section{ABSTRAK}

Latar Belakang : Peningkatan prevalensi sindrom metabolik berkontribusi terhadap peningkatan kejadian penyakit kardiovaskular dan diabetes. Kondisi dislipidemia dan hiperglikemia yang terjadi pada penderita sindrom metabolik mengindikasikan adanya akumulasi radikal bebas. Peningkatan radikal bebas dan penurunan mekanisme pertahanan antioksidan menghasilkan peningkatan derajat stres oksidatif, yang dapat digambarkan dengan kadar MDA. Buah pisang kepok mengandung antioksidan, vitamin, serat, inulin, dan pati resisten yang berpotensi menurunkan kadar MDA melalui pencegahan oksidasi lipid. Penelitian ini bertujuan untuk mengetahui pengaruh buah pisang kepok terhadap kadar MDA hati pada tikus pra-sindrom metabolik.

Metode : Jenis penelitian ini adalah eksperimental dengan post-test only with randomized control group design. Sebanyak 28 ekor tikus Sprague Dawley pra-sindrom metabolik dibagi secara acak menjadi 4 kelompok: K- (hanya diberikan pakan standar), $K+$ (pakan standard dan induksi STZ(Streptozotocin) dan NAD (nicotinamide)), serta P1, P2 (diberikan pakan standar, induksi STZ dan NAD, serta pisang kepok dengan dosis 4,5g/200gBB dan 9g/200gBB selama 21 hari). Pengukuran MDA hati dilakukan dengan metode TBARS (2-ThioBarbituric Acid Reactive Substance). Data dianalisis dengan uji Anova dan post-hoc LSD.

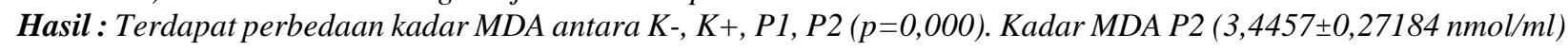
lebih rendah daripada $K+(8,7800 \pm 0,33724 \mathrm{nmol} / \mathrm{ml})$ dan $P 1(6,0243 \pm 0,50695 \mathrm{nmol} / \mathrm{ml})$, tetapi lebih tinggi daripada $K-(2,3029 \pm 0,20766 \mathrm{nmol} / \mathrm{ml})$. Hasil uji post-hoc LSD tentang perbedaan kadar MDA antarkelompok menunjukkan signifikansi sebesar $p=0,000$.

Simpulan : Pemberian buah pisang kepok selama 21 hari pada dosis 9g/200gBB/hari dapat membuat kadar MDA pada tikus pra-sindrom metabolik menjadi lebih rendah.

Kata kunci : Buah pisang kepok, antioksidan, inulin, kadar MDA (malondialdehyde)

\section{PENDAHULUAN}

Penyakit tidak menular menjadi penyebab utama kematian secara global. Sebanyak 38 juta $(68 \%)$ dari 56 juta kematian di dunia pada tahun 2012 disebabkan oleh penyakit tidak menular.
Penyebab utama kematian pada kelompok penyakit tidak menular, diantaranya adalah diabetes mellitus dan penyakit kardiovaskular. ${ }^{1}$ Sindrom metabolik merupakan kumpulan faktor risiko metabolik yang 
berkontribusi dalam peningkatan risiko diabetes mellitus dan penyakit kardiovaskuler.

Sindrom metabolik merupakan suatu kondisi ketidaknormalan metabolisme dalam tubuh, yang ditandai dengan adanya tiga atau lebih dari tanda dan gejala, meliputi obesitas sentral, hipertrigliseridemia, kadar HDL rendah, tekanan darah tinggi, serta kadar glukosa darah puasa tinggi. $^{2}$ Hasil penelitian di Kota Bogor menunjukkan bahwa prevalensi sindrom metabolik pada tahun 2011-2012 sebesar 18,7\%. ${ }^{3}$ Sementara itu, penelitian pada kalangan eksekutif di Jakarta menunjukkan hasil prevalensi sindrom metabolik yang lebih tinggi, yaitu sebesar $21,6 \%{ }^{4}$ Peningkatan prevalensi sindrom metabolik diawali dengan banyaknya jumlah individu yang memiliki dua faktor risiko dari sindrom metabolik, yang kemudian disebut sebagai kelompok pra-sindrom metabolik. Hasil penelitian terhadap kalangan tenaga kesehatan di Brazil menyatakan adanya prevalensi pra-sindrom metabolik sebesar $12,1 \%$ pada laki-laki dan $8,4 \%$ pada perempuan. ${ }^{5}$

Kondisi hiperkolesterolemia, kadar kolesterol LDL tinggi, dan hiperglikemia yang terjadi pada penderita pra-sindrom metabolik mengindikasikan adanya akumulasi radikal bebas dalam tubuh. Peningkatan radikal bebas yang disertai dengan menurunnya mekanisme pertahanan antioksidan akan menstimulasi proses peroksidasi lipid yang mengakibatkan terjadinya peningkatan derajat stres oksidatif. ${ }^{6}$ Hasil peroksidasi lipid berupa senyawa aldehida, yaitu malondialdehyde (MDA) dapat dijadikan sebagai gambaran derajat stres oksidatif dalam tubuh. ${ }^{7}$ Penggunaan MDA untuk mengetahui derajat stres oksidatif didasarkan pada reaktivitasnya yang tinggi baik di dalam maupun di luar sel. Reaktivitas tinggi membuat MDA mampu berinteraksi dengan beberapa biomolekul, seperti asam nukleat dan protein, yang kemudian dapat menghasilkan kerusakan fungsi sel. ${ }^{8}$

Kandungan serat dan antioksidan dalam buah dan sayur diketahui dapat berdampak positif pada penurunan profil lipid dan peningkatan aktivitas antioksidan, yang kemudian dapat menurunkan kadar malondialdehyde (MDA). Pisang merupakan salah satu buah yang memiliki banyak manfaat bagi kesehatan. ${ }^{9,10}$ Pisang kepok (Musa paradisiaca forma typical) merupakan salah satu jenis pisang yang termasuk dalam jenis pisang plantain, memiliki kandungan pati resisten dan serat yang tinggi. Kandungan pati resisten dalam buah pisang kepok berkisar antara 61-73\%." ${ }^{11}$ Penelitian lain menyatakan bahwa pisang mengandung inulin dalam jumlah yang cukup, serta mengandung FOS (frukto-oligosakarida) sebesar 0,3\%. ${ }^{12,13}$ Penelitian tentang identifikasi kadar antioksidan dalam banana drink berbasis ekstrak tepung pisang kepok, diketahui bahwa kadar vitamin $\mathrm{C}$ dan total fenolik dalam buah pisang kepok, secara berurutan adalah $0,48315 \mathrm{mg} / 100 \mathrm{~g}$ (rendah) dan 243,373 mg/ $100 \mathrm{~g}$ (tinggi). ${ }^{14}$ Penelitian tentang kandungan fenol pada pisang mengungkapkan bahwa senyawa fenol dalam pisang memberikan kontribusi kuat terhadap aktivitas antioksidan sehingga dapat berdampak positif dalam pencegahan oksidasi lipid. ${ }^{15}$ Penelitian pada subjek diabetes mellitus tipe 2 dan hiperkolesterolemia menyebutkan adanya efek penurunan glukosa darah dan profil lipid yang disebabkan oleh konsumsi pisang sebanyak 250 gram/ hari dan $500 \mathrm{gram} /$ hari. Penelitian tersebut menyatakan bahwa adanya Soluble Indigestible Fractions (sIF) dalam pisang, yang tidak dapat tercerna dan terserap dalam usus halus tetapi mengalami fermentasi oleh bakteri dalam kolon bertanggung jawab terhadap penurunan kadar kolesterol darah. ${ }^{16}$

Penelitian tentang pengaruh buah pisang kepok matang terhadap kadar malondialdehyde (MDA) belum pernah dilakukan baik pada hewan coba maupun manusia. Oleh karena itu peneliti ingin mengetahui tentang pengaruh pemberian buah pisang kepok (Musa paradisiaca forma typical) terhadap kadar malondialdehyde pada tikus Sprague dawley.

\section{METODE PENELITIAN}

Penelitian ini menggunakan jenis penelitian eksperimental dengan post-test only with randomized control group design. Sampel pada penelitian ini adalah tikus jantan galur Sprague Dawley berumur 8-12 minggu. Tikus Sprague Dawley yang digunakan adalah tikus yang sehat ditandai dengan fisik yang terihat sehat dan tidak memiliki cacat, serta bergerak secara aktif. Sementara itu, kriteria eksklusi adalah jika tikus sakit dan mengalami perubahan perilaku (tidak mau makan dan minum, serta lemas), serta mengalami penurunan berat badan secara drastis. Besar sampel minimal untuk tiap kelompok dalam penelitian ini ditentukan berdasarkan rumus Federer (t-1)(n1) $\geq 15$, dimana $t$ merupakan jumlah kelompok dalam penelitian, sedangkan $\mathrm{n}$ merupakan besar sampel setiap kelompok perlakuan. Jumlah kelompok dalam penelitian ini adalah 4 kelompok, terdiri dari: 1) kelompok kontrol negatif (K-); 2) kelompok kontrol positif $(\mathrm{K}+)$; 3) kelompok perlakuan 1 (P1); 4) kelompok perlakuan 2 (P2). Besar sampel minimal yang didapat dari hasil perhitungan adalah 6 ekor untuk setiap kelompok. 
Penelitian ini menggunakan 7 ekor tikus pada setiap kelompok sebagai langkah antisipasi drop-out. Dengan demikian, didapatkan jumlah total sampel sebanyak 28 ekor.

Sebanyak 28 tikus Sprague dawley jantan dibagi secara acak menjadi 4 kelompok $(\mathrm{K}-, \mathrm{K}+, \mathrm{P} 1$, $\mathrm{P} 2$ ). Seluruh tikus tersebut diaklimatisasi selama 3 hari dalam kandang individu dan diberikan pakan standar, yaitu AD-II serta air minum ad libitum. Setiap 100 gram pakan standar AD-II mengandung air $12 \%$, abu 7\%, protein kasar 15\%, lemak kasar 3$7 \%$, karbohidrat $51 \%$, serat kasar 6\%, kalsium 0,9$11 \%$, phosphor $0,6-0,9 \%$, antibiotika serta coccidiostat maksimal sebanyak $20 \mathrm{mg} /$ hari. Setiap hari dilakukan pembersihan kandang tikus dan setiap tiga hari sekali dilakukan penimbangan berat badan tikus. Setelah masa adaptasi, yaitu pada hari ke-4 tikus pada kelompok $\mathrm{K}+, \mathrm{P} 1$, dan $\mathrm{P} 2$ mendapatkan induksi nicotinamide (NAD) sebesar $230 \mathrm{mg} / \mathrm{kgBB}$ dan streptozotocin (STZ) sebanyak $65 \mathrm{mg} / \mathrm{kgBB}$ secara intraperitoneal, sedangkan Ktidak diberi induksi. ${ }^{17}$ Induksi tersebut dilakukan untuk mendapatkan kondisi hiperglikemia, hipertrigiseridemia, dan hiperkolesterolemia (kondisi pra-sindrom metabolik) pada tikus. Kadar glukosa darah tikus normal adalah $55-135 \mathrm{mg} / \mathrm{dl}$ dan kadar trigliserida normal adalah $25-145 \mathrm{mg} / \mathrm{dl} .{ }^{18}$ Kondisi hiperglikemia $(>135 \mathrm{mg} / \mathrm{dl})$ dan hiperkolesterolemia $(>110 \mathrm{mg} / \mathrm{dl})$ pada kelompok $\mathrm{K}+, \mathrm{P} 1$, dan $\mathrm{P} 2$ dapat terlihat pada hari ke-8..$^{18,19}$ Mulai hari ke-8 sampai hari ke-29, kelompok P1 mendapatkan intervensi buah pisang kepok sebanyak 4,5 gram/200 gram berat badan/hari serta pakan standar dan air minum ad libitum, dan kelompok P2 mendapatkan intervensi buah pisang kepok sebanyak 9 gram/200 gram berat badan/hari serta pakan standar dan air minum ad libitum. Buah pisang diberikan dalam bentuk lumatan untuk mempermudah intervensi. Sementara itu, kelompok $\mathrm{K}$ - dan $\mathrm{K}+$ tidak diberikan intervensi buah pisang, tetapi diberikan pakan standar dan air minum ad libitum. Setelah masa intervensi selesai, semua tikus pada tiap-tiap kelompok dianastesi dan dibedah untuk mengambil organ hati. Organ hati tersebut kemudian diperiksa untuk mengetahui kadar MDA didalamnya.

Variabel bebas pada penelitian ini adalah pemberian buah pisang kepok (Musa paradisiaca forma typical) dengan dosis 4,5 gram/200 gram berat badan/hari dan 9 gram $/ 200$ gram berat badan/hari. Variabel terikat pada penelitian ini adalah kadar MDA (malondialdehyde). Pisang kepok (Musa paradisiaca forma typical) yang digunakan pada penelitian ini adalah buah pisang kepok matang dengan ciri kulit buah berwarna hijau kekuningan dan memiliki daging yang padat. Lumatan buah pisang diperoleh dengan cara pisang dikupas, lalu daging buah dihomogenisasi tanpa penambahan air dan diberikan ke tikus menggunakan sonde dengan dosis 4,5 gram dan 9 gram. Dosis 4,5 gram diberikan dalam satu kali pemberian, sedangkan dosis 9 gram diberikan dalam dua kali pemberian per hari, dengan pertimbangan volume maksimal lambung tikus $\pm 5 \mathrm{cc}$. Sementara itu, kadar Malondialdehyde (MDA) merupakan kadar produk hasil peroksidasi lipid berupa senyawa aldehida yang diambil dari hati tikus. Pengambilan organ hati dilakukan dengan cara memberikan anastesi pada tikus, kemudian dilanjutkan dengan dislokasi pada bagian leher tikus dan pembedahan. Organ hati diambil dan dicuci dengan $\mathrm{NaCl} 0,9 \%$, kemudian dimasukkan dalam larutan PBS. Pengukuran MDA hati dilakukan dengan metode TBARS (2ThioBarbituric Acid Reactive Substance). Nilai kadar MDA diperoleh dari hasil plot terhadap kurva standar MDA.

Pengujian kandungan zat gizi dalam buah pisang kepok matang juga dilakukan dalam penelitian ini. Uji proksimat dilakukan untuk mengetahui kadar abu total (metode dry ashing), kadar air total (metode termogravimetri), kadar lemak total (metode soxhletasi), kadar protein total ( metode kjeldahl), serta kadar karbohidrat total. Sementara itu, uji kandungan inulin dilakukan dengan metode HPLC (High Performance Liquid Chromatography) dan serat kasar diuji dengan metode gravimetri. Aktivitas antioksidan dianalisis dengan metode DPPH (1,1-diphenyl-2picrylhydrazyl). Data hasil nilai proksimat, kandungan inulin, serat kasar, serta antioksidan dari buah pisang kepok matang dapat menjadi data pelengkap untuk mengetahui pengaruh pemberian buah pisang kepok matang terhadap kadar malondialdehyde pada hewan coba. Pemeliharaan hewan coba, intervensi, pengambilan sampel, pemeriksaan biokimia sampel, serta pengujian proksimat, aktivitas antioksidan, dan serat kasar buah pisang kepok dilaksanakan di PAU Pusat Studi Pangan dan Gizi Universitas Gajah Mada. Sementara itu, pengujian kadar inulin dilaksanakan di LPPT Universitas Gajah Mada Yogyakarta. Penelitian ini berlangsung dari bulan Juni sampai Juli 2015.

Data yang diperoleh merupakan data primer yang diambil dari hasil penelitian, yaitu data hasil pemeriksaan kadar MDA setelah dilakukan intervensi dan data hasil penimbangan berat badan. Pengolahan data dilakukan dengan program komputer. Normalitas data diuji menggunakan uji 
Saphiro-Wilk karena jumlah sampel $\leq 50$. Kemudian, data hasil penimbangan berat badan diuji dengan uji statistik paired t-test jika data berdistribusi normal dan uji Wilcoxon jika data berdistribusi tidak normal. Data delta berat badan diuji menggunakan uji non-parametrik KruskalWallis. Sementara itu, data hasil pemeriksaan kadar MDA diuji dengan uji statistik parametrik menggunakan one way ANOVA dan uji lanjut posthoc LSD dengan taraf kepercayaan sebesar $95 \%$ dan $\alpha=0,05$. Seluruh pelaksanaan penelitian ini telah memperoleh persetujuan dari Komite Etik
Penelitian Kesehatan Fakultas Kedokteran Universitas Diponegoro.

\section{HASIL PENELITIAN \\ Hasil Uji Kandungan Zat Gizi Buah Pisang Kepok}

Uji kandungan zat gizi buah pisang kepok matang, meliputi uji proksimat, kandungan inulin, serat kasar, dan antioksidan. Berikut merupakan hasil uji kandungan zat gizi buah pisang kepok matang per 100 gram:

Tabel 1. Kandungan Zat Gizi Buah Pisang Kepok Matang per 100 gram

\begin{tabular}{lc}
\hline \multicolumn{1}{c}{ Zat Gizi } & Kadar \\
\hline Air & $65,94 \%$ \\
Abu & $0,72 \%$ \\
Lemak & $0,095 \%$ \\
Protein & $1,755 \%$ \\
Karbohidrat & $31,49 \%$ \\
\hline Total & $100 \%$ \\
\hline Serat Kasar & $1,14 \%$ \\
Inulin & $126,50 \mathrm{mg}$ \\
Antioksidan & $12,3472 \%$ \\
\hline
\end{tabular}

\section{Kondisi Setelah Induksi STZ dan NAD}

Penelitian ini menggunakan induksi NAD dan STZ untuk mendapatkan kondisi pra-sindrom metabolik pada hewan coba. Kondisi pra-sindrom metabolik terjadi jika individu mengalami dua dari lima faktor risiko, meliputi obesitas sentral, hipertrigliseridemia, kadar HDL rendah, tekanan darah tinggi, serta kadar glukosa darah puasa tinggi. Berdasarkan hasil penelitian diketahui bahwa kelompok yang diinduksi STZ dan NAD, yaitu $\mathrm{K}+$,
P1, dan P2 telah mengalami hiperglikemia (glukosa darah>135 $\mathrm{mg} / \mathrm{dl}$ ) dan hiperkolesterolemia (kolesterol $>110 \mathrm{mg} / \mathrm{dl}$ ), sedangkan $\mathrm{K}$ - tetap normal. Sementara itu, kadar trigliserida pada semua kelompok masih berada dalam rentang nilai normal. Dengan demikian, kondisi pra-sindrom metabolik belum terjadi, tetapi hewan coba pada $\mathrm{K}+, \mathrm{P} 1$, dan P2 berisiko mengalami pra-sindrom metabolik karena telah mengalami hiperglikemia dan hiperkolesterolemia.

Tabel 2. Hasil Pengkondisian Tikus Pra-Sindrom Metabolik

\begin{tabular}{lcc}
\hline \multicolumn{1}{c}{ Kategori } & Nilai Normal & $\begin{array}{c}\text { Hasil } \\
\text { Rerata } \pm \text { s.b. }\end{array}$ \\
\hline Kadar glukosa darah puasa & $55-135 \mathrm{mg} / \mathrm{dl}$ & $221,18 \pm 5,17 \mathrm{mg} / \mathrm{dl}$ \\
Kadar trigliserida & $25-145 \mathrm{mg} / \mathrm{dl}$ & $81,56 \pm 6,54 \mathrm{mg} / \mathrm{dl}$ \\
Kadar kolesterol & $<110 \mathrm{mg} / \mathrm{dl}$ & $179,34 \pm 6,28 \mathrm{mg} / \mathrm{dl}$ \\
\hline
\end{tabular}

\section{Rerata Berat Badan Sampel}

Data hasil pengukuran berat badan hewan coba dikelompokkan menjadi dua bagian, yaitu sebelum dan setelah induksi, serta sebelum dan setelah intervensi. Hasil analisis berat badan tikus sebelum dan setelah induksi disajikan pada Tabel 3. Sementara itu, data hasil analisis berat badan tikus sebelum dan setelah intervensi disajikan pada Tabel 4.

Tabel 3. Hasil Analisis Rerata Berat Badan Sebelum dan Sesudah Induksi STZ dan NAD

\begin{tabular}{ccccccc}
\hline Kelompok & $\mathbf{N}$ & $\begin{array}{c}\text { Sebelum } \\
\text { Rerata } \pm \text { s.b. } \\
\text { (gram) }\end{array}$ & $\begin{array}{c}\text { Sesudah } \\
\text { Rerata } \pm \text { s.b. } \\
\text { (gram) }\end{array}$ & $\begin{array}{c}\Delta \\
\text { Rerata } \pm \text { s.b } \\
\text { (gram) }\end{array}$ & $\mathbf{\%} \Delta$ & $\mathbf{P}$ \\
\hline K- & 7 & $108,14 \pm 16,48$ & $112,57 \pm 18,13$ & $4,42 \pm 2,22^{\mathrm{a}}$ & 4,08 & $0,002^{\mathrm{b}^{*}}$ \\
$\mathrm{~K}+$ & 7 & $144,42 \pm 28,28$ & $139,71 \pm 24,98$ & $-4,71 \pm 3,35^{\mathrm{a}}$ & $-3,26$ & $0,018^{\mathrm{c}^{*}}$ \\
$\mathrm{P} 1$ & 7 & $125,71 \pm 9,65$ & $122,00 \pm 7,72$ & $-3,71 \pm 3,03^{\mathrm{a}}$ & $-2,95$ & $0,018^{\mathrm{b}^{*}}$ \\
P2 & 7 & $123,28 \pm 24,75$ & $116,28 \pm 27,75$ & $-7,00 \pm 4,61^{\mathrm{a}}$ & $-5,67$ & $0,007^{\mathrm{b}^{*}}$ \\
\hline
\end{tabular}


Tabel 4. Hasil Analisis Rerata Berat Badan Sebelum dan Setelah Intervensi

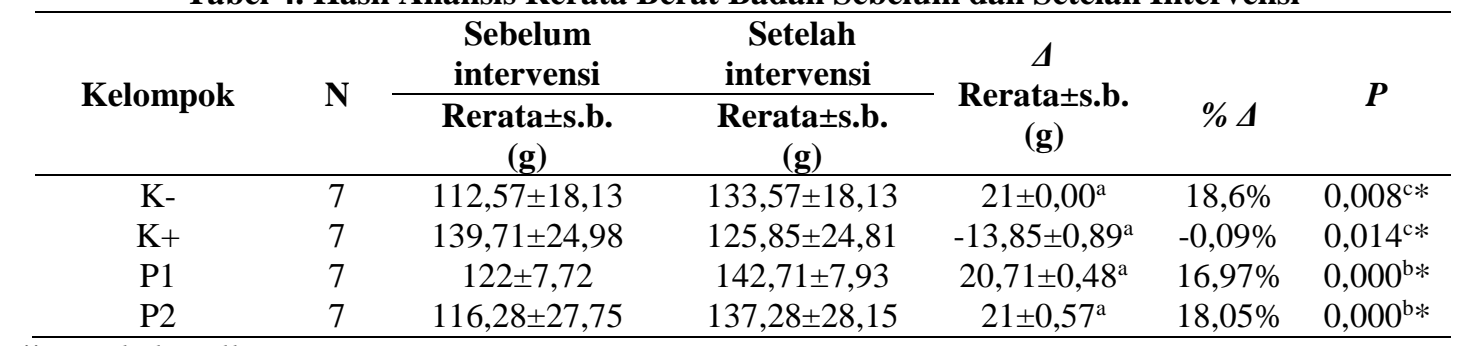

${ }^{a} \mathrm{Uji}$ Kruskal-Wallis

${ }^{b}$ Uji Paired t-test

${ }^{c}$ Uji Wilcoxon

*beda bermakna

Tabel 3 dengan jelas memperlihatkan terjadinya penurunan berat badan pada kelompok yang diinduksi STZ $(\mathrm{K}+, \mathrm{P} 1, \mathrm{P} 2)$ dan kenaikan berat badan pada kelompok kontrol negatif. Uji Paired $t$ test dan Wilcoxon menunjukkan bahwa terdapat perbedaan yang bermakna antara berat badan sebelum dan setelah induksi STZ pada masingmasing kelompok. Namun, hasil uji Kruskall Wallis menunjukkan bahwa tidak terdapat perbedaan signifikan antara delta tiap kelompok.

Tabel 4 memperlihatkan adanya perbedaan yang bermakna antara berat badan sebelum dan setelah intervensi. Hasil analisis perubahan berat badan yang di uji dengan Kruskall wallis menunjukan bahwa terdapat perbedaan perubahan berat badan yang signifikan sebelum dan setelah intervensi $(p=0,000)$. Analisis data menunjukkan adanya perubahan berat badan terendah pada kelompok kontrol positif $(0,09 \%)$ dan perubahan berat badan yang tertinggi pada kelompok kontrol negatif $(18,6 \%)$.

\section{Kadar Malondialdehyde (MDA)}

Data hasil pemeriksaan MDA pada liver diuji dengan Saphiro-Wilk untuk mengetahui kenormalitasannya dan diuji dengan Levene test untuk mengetahui homogenitas varians. Hasil uji menunjukkan bahwa data berdistribusi normal (kontrol negatif $\mathrm{p}=0,966$, kontrol positif $\mathrm{p}=0,812$, perlakuan $1 \mathrm{p}=0,972$, perlakuan $2 \mathrm{p}=0,946)$ dan homogen $(\mathrm{p}=0,133)$. Analisis data dilakukan dengan menggunakan uji statistik parametrik one way ANOVA karena data berdistribusi normal dan varians data homogen. Berikut merupakan hasil uji one way ANOVA:

Tabel 5. Hasil Analisis Rerata Kadar MDA dan Pengaruh Pemberian Buah Pisang Kepok Pada Masing Masing Kelompok

\begin{tabular}{cccc}
\multicolumn{5}{c}{ Masing Kelompok } \\
\hline Kelompok & N & Rerata \pm s.b. $(\mathbf{n m o l} / \mathbf{m l})$ & $\boldsymbol{P}$ \\
\hline K- & 7 & $2,3029 \pm 0,20766^{*}$ & \\
K+ & 7 & $8,7800 \pm 0,33724^{*}$ & 0,000 \\
P1 & 7 & $6,0243 \pm 0,50695^{*}$ & \\
P2 & 7 & $3,4457 \pm 0,27184^{*}$ & \\
*beda bermakna & &
\end{tabular}

Uji one way anova. Uji post-hoc LSD: diperoleh semua perbedaan antarkelompok $\mathrm{p}=0,000$.

Hasil analisis data dengan one way ANOVA menunjukkan bahwa $p=0,000$. Berdasarkan hasil tersebut, maka dapat disimpulkan terdapat pengaruh pemberian buah pisang kepok terhadap kadar MDA. Kelompok kontrol negatif memiliki data rerata yang paling rendah $(2,3029 \pm 0,20766$ $\mathrm{nmol} / \mathrm{ml}$ ) jika dibandingkan dengan kelompok kontrol positif $(8,7800 \pm 0,33724 \mathrm{nmol} / \mathrm{ml})$, kelompok perlakuan $1(6,0243 \pm 0,50695 \mathrm{nmol} / \mathrm{ml})$, dan kelompok perlakuan $2 \quad(3,4457 \pm 0,27184$ $\mathrm{nmol} / \mathrm{ml}$ ). Selanjutnya dilakukan analisis lebih lanjut untuk mengetahui signifikansi perbedaan antarkelompok perlakuan menggunakan salah satu analisis post hoc. Pemilihan analisis post hoc didasarkan pada besar koefisien keragaman (KK). Uji post hoc Least Significant Different (LSD) dipilih karena hasil perhitungan koefisien keragaman $(\mathrm{KK}=6,798 \%)$ termasuk dalam $\mathrm{KK}$ sedang.

Hasil uji post-hoc menunjukkan bahwa semua perbedaan rerata antarkelompok memiliki $p=0,000$. Dengan demikian, diketahui bahwa perbedaan rata-rata kadar MDA pada semua kelompok berbeda secara bermakna. Selain itu, diketahui bahwa $\mathrm{K}$ - dan $\mathrm{K}+(6,48)$ memiliki perbedaan rerata (mean difference) paling besar, diikuti dengan $\mathrm{K}+$ dan $\mathrm{P} 2$ (5,33), $\mathrm{P} 1$ dan $\mathrm{K}-(3,72)$, 
$\mathrm{K}+$ dan $\mathrm{P} 1(2,75), \mathrm{P} 1$ dan $\mathrm{P} 2(2,58)$, dan $\mathrm{P} 2$ dan $\mathrm{K}+$ $(1,14)$.

\section{PEMBAHASAN}

Prevalensi sindrom metabolik yang tinggi, membuat sindrom metabolik menjadi masalah kesehatan utama di dunia. Sindrom metabolik ditandai dengan adanya akumulasi lemak pada area abdominal (obesitas sentral), dislipidemia, peningkatan glukosa darah, dan tingginya tekanan darah. Kondisi sindrom metabolik dapat diawali dengan memiliki dua faktor risiko dari sindrom metabolik. Individu dengan karakteristik tersebut masuk dalam kelompok pra-sindrom metabolik. Pengondisian pra-sindrom metabolik pada penelitian ini menggunakan induksi nicotinamide (NAD) dan streptozotocin (STZ). Kondisi prasindrom metabolik pada penelitian ini tidak dapat tercapai karena kadar trigliserida hewan coba masih berada dalam rentang nilai normal, meskipun $\mathrm{K}+$, P1, dan P2 memiliki kadar trigliserida yang lebih tinggi daripada K-. Hal tersebut dapat terjadi karena defisiensi insulin pada kondisi hiperglikemia mengakibatkan acetyl-CoA carboxylase tidak teraktivasi. Acetyl-CoA carboxylase berperan dalam reorganisasi glukosa dan asam amino menjadi acyl $\mathrm{CoA}$, yang merupakan bagian dari proses pembentukan triacylgycerol atau trigliserida. Dengan demikian, pembentukan trigliserida dari glukosa dan asam amino terganggu. Akan tetapi di sisi lain, peningkatan degradasi lemak juga menghasilkan acyl CoA dan gliserol yang kemudian teresterifikasi dan mengalami proses pembentukan trigliserida dan fosfolipid sehingga kadar trigliserida pada kelompok induksi STZ dan NAD lebih tinggi dibanding K-, meskipun tidak melebihi batas normal. ${ }^{20}$

Hasil analisis berat badan pada sebelum dan sesudah induksi STZ dan NAD menunjukkan adanya penurunan berat badan pada K-, P1, P2 . Penurunan berat badan pada K-, P1, P2 setelah induksi STZ terjadi karena adanya perusakan sel- $\beta$ Langerhans pankreas oleh STZ. Streptozotocin merupakan donor NO (nitric oxide). NO yang dihasilkan sewaktu STZ mengalami metabolisme dalam sel, berkontribusi terhadap kerusakan sel- $\beta$ pankreas melalui peningkatan aktivitas guanilil siklase dan pembentukan cGMP (cyclic Guanosine Monophosphate). Selain itu, STZ juga dapat menghasilkan oksigen reaktif yang berperan tinggi dalam kerusakan sel- $\beta$ pankreas. Dampak dari mekanisme tersebut adalah terjadinya penurunan fungsi dari reseptor insulin dan penurunan kemampuan sel- $\beta$ pankreas dalam memproduksi insulin. Dengan demikian, akan terjadi penurunan penyimpanan glukosa dalam tubuh dan peningkatan penggunaan protein otot sebagai substrat dalam produksi energi sehingga dapat terjadi penurunan berat badan. $^{21,22}$ Rata-rata besar penurunan berat badan pada kelompok yang diinduksi STZ adalah sebesar 5,14 gram. Hasil penelitian ini sesuai dengan penelitian sebelumnya yang menyatakan penurunan berat badan sekitar \pm 5 gram setelah diinduksi STZ. ${ }^{23}$

Berkebalikan dengan kondisi tersebut, hasil analisis berat badan sebelum dan setelah intervensi menunjukkan adanya peningkatan berat badan pada kedua kelompok perlakuan dan kelompok kontrol negatif. Peningkatan berat badan yang terjadi pada kedua kelompok perlakuan merupakan hasil pengaruh dari pemberian pisang kepok. Pisang kepok terbukti mampu melemahkan efek toksik dari STZ sehingga terjadi perbaikan metabolisme glukosa. Selanjutnya, perbaikan metabolisme glukosa akan meningkatkan penggunaan zat gizi dalam makanan yang diasup sehingga terjadi peningkatan berat badan. Perubahan berat badan hewan coba selama penelitian ini sesuai dengan hasil beberapa penelitian sebelumnya, yang menyatakan adanya penurunan berat badan karena induksi STZ dan peningkatan berat badan setelah diberi intervensi. ${ }^{22-24}$

Selain terjadi perubahan berat badan, terjadi pula kondisi hiperglikemia dan hiperkolesterolemia pada hewan coba. Kondisi hiperglikemia berhubungan dengan peningkatan kadar kolesterol, LDL-C (Low-Density Lipoprotein Cholesterol), VLDL-C (Very Low-Density Lipoprotein Cholesterol), trigliserida, dan penurunan HDL-C (High-Density Lipoprotein Cholesterol). Kondisi tersebut terjadi akibat adanya resistensi insulin yang kemudian menyebabkan pengaktifan hormon sensitif lipase pada sel lemak sehingga terjadi hidrolisis trgliserida. Hasil hirolisis trigliserida, yaitu asam lemak dan gliserol akan lepas ke dalam darah. Jumlah berlebihan dari asam lemak dapat meningkatkan perubahan beberapa asam lemak menjadi fosfolipid dan kolesterol. ${ }^{25}$

Peningkatan metabolisme lemak dapat menyebabkan peningkatan produksi Reactive Oxygen Species (ROS) di sirkulasi dan di sel adiposa. Peningkatan ROS dalam sel adiposa dapat menyebabkan keseimbangan reaksi reduksi oksidasi terganggu sehingga mengakibatkan penurunan enzim antioksidan di dalam sirkulasi. ${ }^{26}$ Selain itu, kondisi hiperglikemia pada penderita sindrom metabolik juga dapat menginduksi stres oksidatif. Peningkatan glukosa darah dapat menghasilkan ketidakseimbangan reaksi oksidasireduksi dalam hepatosit. Dengan demikian, kondisi 
hiperglikemia melalui peningkatan AGEs (Advanced Glycation End Products) memfasilitasi produksi radikal bebas lewat gangguan pada produksi ROS, seperti gangguan pada kinerja SOD (Superoxide Dismutase) dan CAT (Catalase). ${ }^{27,28}$ Kondisi tersebut dikenal sebagai stres oksidatif.

Produksi ROS yang berlebihan dalam kondisi stres oksidatif dapat memicu terjadinya peroksidasi polyunsaturated fatty acids (PUFA). Proses peroksidasi tersebut menghasilkan akumulasi hidroksiperoksida, molekul-molekul yang tidak stabil, yang mempunyai efek toksik pada sel baik melalui proses degradasi non-enzimatik dengan berbagai senyawa, termasuk aldehida maupun secara langsung. Malondialdehyde (MDA) merupakan produk akhir dari degradasi oksidatif non-enzimatik PUFA, yang telah lama digunakan sebagai tanda peroksidasi lipid. ${ }^{26,27}$ Kadar MDA yang lebih tinggi dari kondisi normal diketahui dapat terjadi pada individu yang menderita hiperglikemia atau diabetes dan hiperkolesterolemia. ${ }^{28,29}$ Sejalan dengan teori tersebut, penelitian ini menunjukkan bahwa kadar MDA pada kelompok $\mathrm{K}+(8,7800 \pm 0,33724$ $\mathrm{nmol} / \mathrm{ml}$ ) lebih tinggi dibandingkan dengan $\mathrm{K}$ $(2,3029 \pm 0,20766 \mathrm{nmol} / \mathrm{ml})$. Kadar MDA yang tinggi mengindikasikan adanya peningkatan peroksidasi lipid yang berhubungan erat dengan tingginya kadar glukosa darah dan menurunnya mekanisme antioksidan enzimatik dan nonenzimatik dalam tubuh. ${ }^{27}$

Buah pisang kepok kuning (Musa paradisiaca forma typical) mengandung pati resisten, inulin, kalsium, senyawa fenolik, betakaroten, vitamin $\mathrm{A}, \mathrm{B} 1, \mathrm{~B} 2, \mathrm{~B} 3, \mathrm{~B} 6, \mathrm{C}$, dan mineral. Kandungan flavonoid dan fenol pada pisang dapat menurunkan konsentrasi kolesterol, asam lemak bebas, dan trigliserid pada serum dan jaringan, serta meningkatkan sensitivitas insulin. Peningkatan sensitivitas insulin oleh flavonoid dengan cara memperbaiki potensi jalur sinyal insulin atau sebagai aktivator reseptor insulin tirosin kinase. ${ }^{16}$ Mekanisme lain dari antioksidan dalam menurunkan kadar MDA adalah melalui penghambatan reaksi oksidasi pada lipid dalam tubuh. Hasil penelitian ini, yang melihat pengaruh antioksidan pisang kepok terhadap kadar MDA sesuai dengan penelitian tentang pengaruh polifenol terhadap kadar MDA tikus hiperkolesterolemia. Penelitian tentang pengaruh pemberian tepung buah kaya akan antioksidan polifenol membuktikan bahwa polifenol efektif dalam menurunkan kadar MDA secara signifikan, baik pada tikus sehat maupun hiperkolesterolemia. ${ }^{29}$
Uji aktivitas antioksidan buah pisang kepok pada penelitian ini menunjukkan hasil sebesar $12,3472 \%$ dengan perbedaan kadar MDA terbesar (antara K+ dan P2), yaitu 60,75\%. Sementara itu, penelitian sebelumnya tentang pengaruh cuka nanas terhadap kadar MDA, didapatkan hasil perbedaan kadar MDA (antara $\mathrm{K}+$ dan perlakuan dosis tertinggi) sebesar $70,62 \%$ dengan aktivitas antioksidan cuka nanas sebesar 69,28 $\pm 0,18 \% .{ }^{30} \mathrm{Jika}$ dilakukan perbandingan antara dua hasil tersebut, terlihat jelas bahwa aktivitas antioksidan pada pisang kepok sangat rendah dibandingkan cuka nanas. Sedangkan hasil perbedaan kadar MDA tidak terlalu jauh berbeda antara pisang kepok dan cuka nanas (berbeda $\pm 10 \%$ ). Dengan demikian, diasumsikan terdapat kandungan lain dalam buah pisang kepok yang berpengaruh terhadap kadar MDA.

Penurunan kadar glukosa darah dan kolesterol dapat juga disebabkan oleh kandungan serat pangan (inulin, FOS, dan jenis serat lain) dan pati resisten yang terdapat pada buah pisang. ${ }^{12,31}$ Efek hipolipidemik serat dapat dihasilkan dari proses fermentasi serat dalam usus besar oleh mikroba. Fermentasi tersebut meliputi serangkaian proses metabolik pada pemecahan senyawa organik secara anaerobik yang menghasilkan energi dari pertumbuhan mikroba dan produksi asam lemak rantai pendek (SCFA), seperti asetat, propionat, dan butirat. Propionat diketahui dapat menginduksi penurunan sintesis kolesterol. Selain menurunkan lipogenesis, serat juga meningkatkan ekskresi empedu feses, yang juga menstimulasi hati untuk melakukan sintesis asam empedu dari kolesterol sehingga serum kolesterol menurun. Sementara itu, efek hipoglikemik dihasilkan dari peningkatan GLP-1 (Glucagon Like Peptide-1) oleh inulin pada proksimal usus besar, yang dapat memodulasi homeostatis glukosa. ${ }^{31,32}$

Penurunan kadar glukosa darah dan kolesterol dapat berpengaruh pada penurunan peroksidasi lipid sehingga dihasilkan kadar MDA yang lebih rendah daripada saat kondisi sakit (hiperglikemia dan hiperkolesterolemia). Sesuai dengan teori tersebut, hasil penelitian ini menunjukkan bahwa rerata kadar MDA hati pada kelompok P1 $(6,0243 \pm 0,50695 \mathrm{nmol} / \mathrm{ml})$ dan P2 $(3,4457 \pm 0,27184 \mathrm{nmol} / \mathrm{ml})$ lebih rendah daripada $\mathrm{K}+(8,7800 \pm 0,33724 \mathrm{nmol} / \mathrm{ml})$. Diantara kelompok $\mathrm{K}+, \mathrm{P} 1$, dan $\mathrm{P} 2$, kadar MDA terendah terdapat pada kelompok P2.

Meskipun dosis tertingi pemberian buah pisang terdapat pada $\mathrm{P} 2$, kadar MDA pada $\mathrm{P} 2$ $(3,4457 \pm 0,27184 \mathrm{nmol} / \mathrm{ml})$ lebih tinggi jika dibandingkan dengan K- $(2,3029 \pm 0,20766$ 
$\mathrm{nmol} / \mathrm{ml})$. Hal tersebut dapat terjadi karena kandungan inulin dalam buah pisang kepok rendah, yaitu $126,50 \mathrm{mg} / 100 \mathrm{~g}$ pisang, atau sekitar $0,126 \%$. Dosis buah pisang kepok pada P2 sebesar 9 gram, berarti terdapat 0,01134 gram inulin dalam dosis tersebut. Jumah kandungan inulin tersebut termasuk sangat rendah bila dibandingkan dengan penelitian lain tentang suplementasi inulin sebesar $0,174 \mathrm{~g} / 100$ $\mathrm{g}$ berat badan. Hasil penelitian pengaruh suplementasi inulin (dosis $0,174 \mathrm{~g} / 100 \mathrm{~g}$ berat badan) terhadap kadar glukosa darah dan kolesterol, menunjukkan bahwa terjadi penurunan kadar glukosa darah dan kolesterol yang signifikan pada kelompok yang diberikan inulin. ${ }^{32}$ Kadar inulin yang rendah dapat membuat inulin tidak mampu menurunkan kadar glukosa darah dan kolesterol hingga mencapai level normal sehingga kadar MDA pada kelompok perlakuan tetap lebih tinggi daripada kelompok K-.

Perbedaan rerata kadar MDA antara semua kelompok di penelitian ini berbeda secara bermakna $p=0,000$. Perbedaan paling besar terdapat pada $\mathrm{K}+$ dengan $\mathrm{K}$ - $(6,47714 \mathrm{nmol} / \mathrm{ml})$, diikuti dengan kelompok $\mathrm{K}+$ dan $\mathrm{P} 2 \quad(5,33429 \mathrm{nmol} / \mathrm{ml})$. Perbedaan terbesar pada $\mathrm{K}+$ dan $\mathrm{K}$ - disebabkan karena $\mathrm{K}+$ mengalami peningkatan peroksidasi lipid pada kondisi pra-sindrom metabolik yang diiringi dengan konsumsi pakan standar tanpa pemberian buah pisang kepok.

Perbedaan rerata kadar MDA antara $\mathrm{K}+$ dan P2 menjadi perbedaan terbesar kedua. Hal tersebut terjadi karena dosis intervensi buah pisang kepok yang diberikan pada P2 merupakan dosis tertinggi dalam penelitian ini. Dengan demikian, pengaruh terbesar dari pisang kepok terhadap kadar MDA liver dapat terlihat pada P2. Pengaruh pemberian pisang kepok terhadap kadar MDA sebagian besar mungkin disebabkan oleh serat pangan dan aktivitas antioksidan serta kandungan zat gizi lain yang tidak diuji pada penelitian ini, seperti FOS, pati resisten, dan betakaroten.

\section{SIMPULAN}

Terdapat pengaruh pemberian buah pisang kepok selama 21 hari terhadap kadar MDA hati tikus Sprague dawley pra-sindrom metabolik $(p=0,000)$. Terdapat perbedaan nilai rerata kadar MDA yang bermakna antara semua kelompok (nilai $p=0,000)$. Dosis pemberian pisang kepok sebesar 9 gram $/ 200$ gram berat badan tikus per hari $(\mathrm{P} 2=$ $3,4457 \pm 0,27184 \mathrm{nmol} / \mathrm{ml}$ ) selama 21 hari memiliki hasil kadar MDA yang lebih rendah daripada $\mathrm{K}+$ $(8,7800 \pm 0,33724 \quad \mathrm{nmol} / \mathrm{ml})$ dan P1 $(6,0243 \pm 0,50695 \mathrm{nmol} / \mathrm{ml})$, tetapi lebih tinggi daripada K- $(2,3029 \pm 0,20766 \mathrm{nmol} / \mathrm{ml})$.

\section{DAFTAR PUSTAKA}

1. World Health Organization. Global status report on noncommunicable diseases 2014. 2014.

2. International Diabetes Federation. The IDF consensus worldwide definition of the metabolic syndrome. 2006.

3. Sirait AM, Sulistiowati E. Sindrom metabolik pada orang dewasa di kota bogor, 2011-2012. 2014;02:2011-2012.

4. Kamso S, Purwantyastuti, Lubis DU, Juwita R, Robbi YK, Besral. Prevalensi dan determinan sindrom metabolik pada kelompok eksekutif di jakarta dan sekitarnya. J Kesehat Masy Nas. Vol. 6, No:85-90.

5. Vidigal FDC, Ribeiro AQ, Babio N, Salas-Salvadó J, Bressan J. Prevalence of metabolic syndrome and pre-metabolic syndrome in health professionals: LATINMETS Brazil study. Diabetol Metab Syndr. 2015;7(1):1-9. doi:10.1186/s13098-015-0003-x.

6. Soliman G.Z. Blood lipid peroxidation (superoxide dismutase, malondialdehyde, glutathione) levels in Egyptian type 2 diabetic patients. Singapore Med J. 2008;49(2):129-136.

7. Catala A. Lipid peroxidation. Vol 1st ed. Croatia: InTech; 2012.

8. Del Rio D, Stewart AJ, Pellegrini N. A review of recent studies on malondialdehyde as toxic molecule and biological marker of oxidative stress. Nutrition, Metabolism and Cardiovascular Disease. 2005;15(4):316-328. doi:10.1016/j.numecd.2005.05.003.

9. Rianti CR, Syauqy A. Pengaruh pemberian pisang (Musa paradisiaca) terhadap kelelahan otot aerob pada atlet sepak takraw. Journal of Nutrition College. 2014:1-25.

10. Kumairoh S, Syauqy A. Pengaruh pemberian pisang ( Musa paradisiaca ) terhadap kelelahan otot anaerob pada atlet sepak takraw. Journal of Nutrition College. 2014.

11. Badan Litbang Pertanian. Yoghurt sinbiotik minuman fungsional kaya serat berbasis tepung pisang. 2013;(3515).

12. Miremadi F, Shah NP. Applications of inulin and probiotics in health and nutrition. International Food Research Journal. 2002;27(7):703-714. doi:10.1007/BF02708379.

13. Kusharto CM. Serat makanan dan peranannya bagi kesehatan. J Gizi dan Pangan. 2006;1(November):45-54.

14. Betaditya D, Lestari LA, Penggalih Mirza HST. Identifikasi kadar antioksidan yang terdapat dalam minuman banana drink berbasis ekstrak tepung pisang kepok (Musa paradisiaca formal typical). Gizi Kesehatan Fakultas Kedokteran Universitas Gajah Mada. 2013;1496:2-7.

15. Deniati SH. Aktivitas antioksidan dan kandungan fenol total beberapa ekstrak bahan alam pangan. Universitas Indonesia. 2006.

16. Cressey R, Kumsaiyai W, Mangklabruks A. Daily consumption of banana marginally improves blood 
glucose and lipid profile in hypercholesterolemic subjects and increases serum adiponectin in type 2 diabetic patients. 2014;52(December):1173-1181.

17. Islam MS, Loots DT. Experimental rodent models of type 2 diabetes: a review. Methods Find Exp Clin Pharmacol. 2009;31(4):249. doi:10.1358/mf.2009.31.4.1373958.

18. Mitruka BM, Rawnsley HM. Clinical biochemical and hematological reference value in normal experimental animals and normal humans. Mason Publishing USA, Inc.; 1981.

19. Maryanto S. Pengaruh pemberian serat buah jambu biji (Psidium guajava L.) terhadap profil lipid serum tikus Sprague Dawley hiperkolesterolemia. 2003.

20. Koolman J, Roehm KH. Color atlas of biochemistry. Vol 2nd ed. New York: Thieme New York; 2005. doi:10.1016/S0968-0004(97)84080-7.

21. Nugroho AE. Animal models of diabetes mellitus : pathology and mechanism of some diabetogenics. Biodiversitas, J Biol Divers. 2006;7(4):378-382. doi:10.13057/biodiv/d070415.

22. Xue WL, Li XS, Zhang J, Liu YH, Wang ZL, Zhang RJ. Effect of Trigonella foenum-graecum (fenugreek) extract on blood glucose, blood lipid and hemorheological properties in streptozotocininduced diabetic rats. Asia Pac J Clin Nutr. 2007;16(SUPPL.1):422-426.

23. Sekar DS, Sivagnanam K, Subramanian S. Antidiabetic activity of Momordica charantia seeds on streptozotocin induced diabetic rats. Pharmazie. 2005;60(5):383-387. doi:10.1248/jhs.52.283.

24. Hwang HJ, Kim SW, Lim JM, Joo JH, Kim HO, Kim HM, et al. Hypoglycemic effect of crude exopolysaccharides produced by a medicinal mushroom Phellinus baumii in streptozotocininduced diabetic rats. Life Sci. 2005;76(26):30693080. doi:10.1016/j.lfs.2004.12.019.

25. Franz MJ. Medical Nutrition therapy for diabetes mellitus and hypoglycemia of nondiabetic origin. In: Krause's Food and the Nutrition Care Process. Vol 13th ed. ; 2012:675-579.

26. Pillon NJ, Soulage CO. Lipid peroxidation byproducts and the metabolic syndrome. In: Biochemistry, Genetics and Molecular Biology. 2012:409-436. doi:10.5772/46019.

27. Tiwari BK, Pandey KB, Abidi AB, Rizvi SI. Markers of oxidative stress during diabetes mellitus. J Biomarkers. 2013;2013:1-8. doi:10.1155/2013/378790.

28. Abolfathi AA, Mohajeri D, Rezaie A, Nazeri M. Protective effects of green tea extract against hepatic tissue injury in streptozotocin-induced diabetic rats. Evidence-based Complement Altern Med. 2012;2012. doi:10.1155/2012/740671.

29. Mateos R, Lecumberri E, Ramos S, Goya L, Bravo L. Determination of malondialdehyde (MDA) by high-performance liquid chromatography in serum and liver as a biomarker for oxidative stress: Application to a rat model for hypercholesterolemia and evaluation of the effect of diets rich in phenolic antioxidant. J Chromatogr B Anal Technol Biomed Life Sci. 2005;827(1):76-82. doi:10.1016/j.jchromb.2005.06.035.

30. Mohamad NE, Yeap SK, Lim KL, et al. Antioxidant effects of pineapple vinegar in reversing of paracetamol-induced liver damage in mice. Chin Med. 2015;10(1):1-10. doi:10.1186/s13020-0150030-4.

31. Galisteo M, Duarte J, Zarzuelo A. Effects of dietary fibers on disturbances clustered in the metabolic syndrome. J Nutr Biochem. 2008;19(2):71-84. doi:10.1016/j.jnutbio.2007.02.009.

32. Nassar SE, Ismail GM, El-damarawi MA, El-din AAA. Effect of inulin on metabolic change produced by fructose diet. Life Sci J. 2013;10(2):1807-1814. 